原著

\title{
より安全な脳動脈瘤手術のための頭蓋底手術の応用
}

\author{
池田 清延，山下 純宏
}

\section{Application of Skull Base Surgery for Safer Clipping Surgery of Intracranial Aneurysm}

Kiyonobu IkEDA, M.D. and Junkoh YAmashita, M.D.

Department of Neurosurgery, Kanazawa University School of Medicine, Kanazawa, Japan

Summary: Although the pterional approach (PA) is the most commonly employed for the intracranial aneurysms in the anterior circulation and of the upper portion of the basilar artery (BA), there are some difficult cases among them in clipping surgery with PA. In the past 8 years, we used skull base approaches to access and treat 41 aneurysms involving the anterior communicating artery complex, middle cerebral artery, proximal internal carotid artery (ICA) or BA. The approaches included orbital osteotomy and orbitozygomatic osteotomy. Removal of the rim and roof of the orbit and additional decompression of the optic nerve and anterior clinoid resection, namely, the orbitocranial approach (OCA) allowed shorter and multi-directional accesses to the highly-located aneurysms with a minimal brain retraction.

OCA was very useful for clipping surgeries of a high BA aneurysm and of a ruptured aneurysm in the anterior circulation with a swollen brain in the acute stage. Orbitozygomatic temporopolar approach, which consists of the frontotemporal and orbitozygomatic osteotomy, allowed more upward visual axis through the temporopolar route and multidirectional working space for a high BA tip aneurysm associated with a short intracranial ICA. Skull base surgeries, used selectively, can provide improved access to highly-located aneurysms and large or giant aneurysms, while minimizing brain retraction.

\author{
Key words: \\ - skull base surgery \\ - intracranial aneurysm
}

Surg Cereb Stroke (Jpn) 26: 175-180, 1998

\section{はじめに}

ウイリス輪前半部および脳底動脈瘤に対して多くは手術 手技が確立されて扔り, pterional approach (PA) ${ }^{13)}$ が一 般的である。しかし本法のみではいくつかの限界がある. すなわち, くも膜下出血 ( $\mathrm{SAH}$ ) 急性期の脳腫脹例, 瘤の 位置 ${ }^{12)}$ や大きさ ${ }^{10)}$ などにより十分な術野と working space の確保ができない場合である.このような症例に対 し，頭蓋底骨の削除は頭蓋底部に局在する脳動脈瘤までの
距離を短縮し, 少ない脳圧排で広い術野を確保し, 安全な 到達処置を可能とする. しかし, 過剰な開頭, 骨削除は避 けるべきであり, 頭蓋底手術の適応を明らかにする必要が ある. 今回, われわれはPAでは到達困難と思われたウイ リス輪前半部ならびに脳底動脈瘤に対し，1）orbitocranial approach $(\mathrm{OCA})^{11)}$, 2) orbitozygomatic temporopolar approach $(\mathrm{OZTA})^{6)}$ を行った. その手術適応を明らか にするため，これら手術アプローチの成績を検討した。

金沢大学 脳神経外科(受稿日 1997.8.13)〔連絡先：テ920-0935 石川県金沢市石引3-1-1 国立金沢病院 脳神経外科 池田清延〕 〔Mailing address: Kiyonobu IkedA, M.D., Department of Neurosurgery, National Kanazawa Hospital, 3-1-1 Ishibiki, Kanazawa, Ishikawa 920-0935, Japan] 


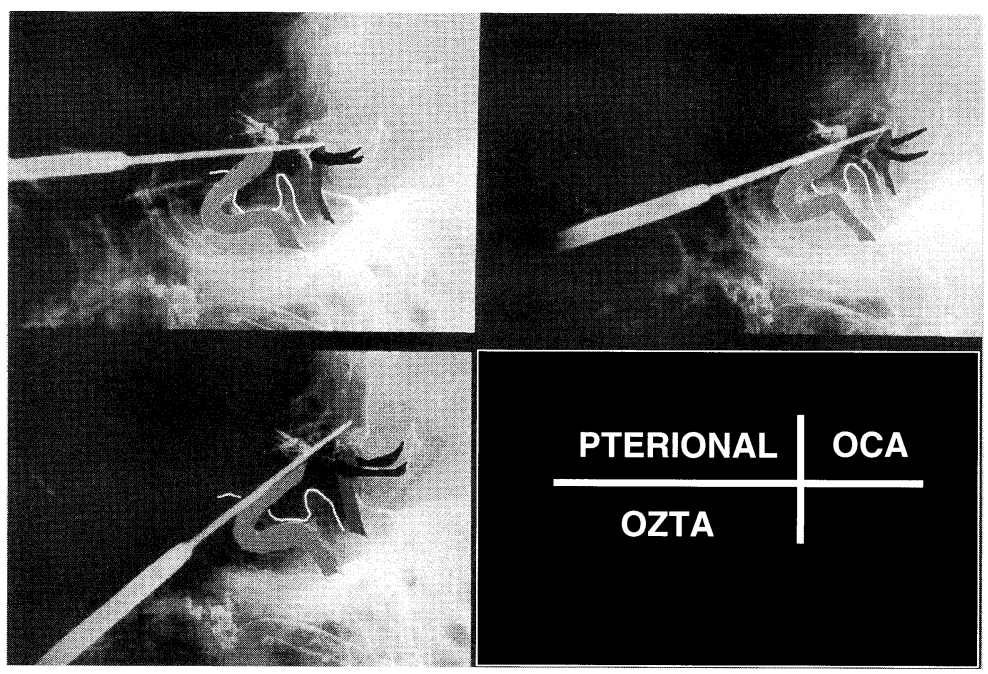

Fig. 1 X-ray photos of a cadaver's head (treated by injection of barium sulfate into cerebral arteries) showing the various visual axis indicated by a probe in the pterional, orbitocranial (OCA), and orbitozygomatic temporopolar approaches (OZTA).

\section{対象および方法}

対象は 1989 年から 1996 年までの過去 8 年間に金沢大学 医学部脳神経外科でウイリス輪前半部ならびに脳底動脈脳 動脈瘤に対し頭蓋底手術アプローチを行った 41 例(前交通 動脈瘤 AC; 9 例, 内项 - 後交通動脈瘤 ICPC; 12 例, 内頸 眼動脈瘤 ICOP; 6例，海綿静脈洞内内頸動脈瘤 ICC; 3 例， 中大脳動脈瘤 $\mathrm{MCA} ; 6$ 例，脳底動脈先端部動脈瘤 $\mathrm{BA}$ tip; 3 例, 脳底動脈一上小脳動脈瘤 BASCA; 2 例)である。なお, 今回は椎骨動脈, 脳底動脈幹脳動脈瘤例は対象より除いた。 くも膜下出血 (SAH) 急性期例は 28 例で, Hunt \& Kosnik 分類の Grade 1 が 9 例, Grade 2 が 4 例, Grade 3 が 8 例, Grade 4 が7例であった。これらの症例に対し，OCAを 39 例 (ICPC 12, ICOP 6, ICC 3, AC 9, MCA 6, BASCA 2, BA tip 1)に, OZTAを3 例(BA tip 3)に行った。なお, OCA や OZTA では骨弁は一塊 (en bloc) として作成した。

\section{成 績}

\section{OCA}

PAに眼窝上縁骨の削除を加えることにより PA では得 られない，より低い位置から見上げる視軸と多方向から観 察できる広い術野が得られた(Fig. 1).

1) $\mathrm{AC}$ 例 (9例)：前頭蓋底より $12 \mathrm{~mm}$ 以上高位で上向 きの large 褞，脳腫脹例に有用であった，開頭範囲をより 正中側に広げ subfrontal routeで少ない前頭葉の圧排とわ ずかな直回切除(退縮脳例では直回切除は不要)により, 瘤 までの距離は短縮し, 瘤周囲と両側 A2 segment が十分に
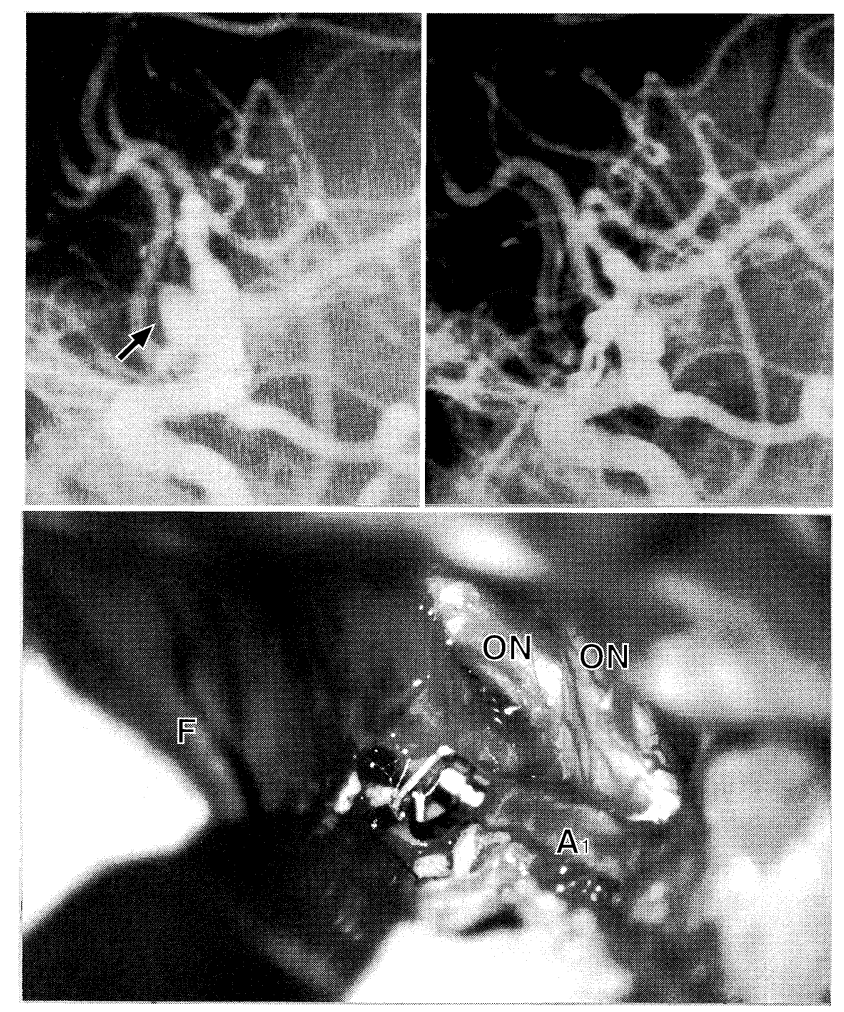

Fig. 2 A case of high anterior communicating artery aneurysm. Angiograms before $(\mathbf{A})$ and after clipping (B). An arrow indicating an aneurysm. An intraoperative photo show-

$\mathbf{A} \mid \mathbf{B}$ ing successful clipping in a wide working space via sub-

C frontal route with the right orbitocranial approach (OCA) (C). F, frontal lobe; Al, anterior cerebral artery; $\mathrm{ON}$, optic nerve. 

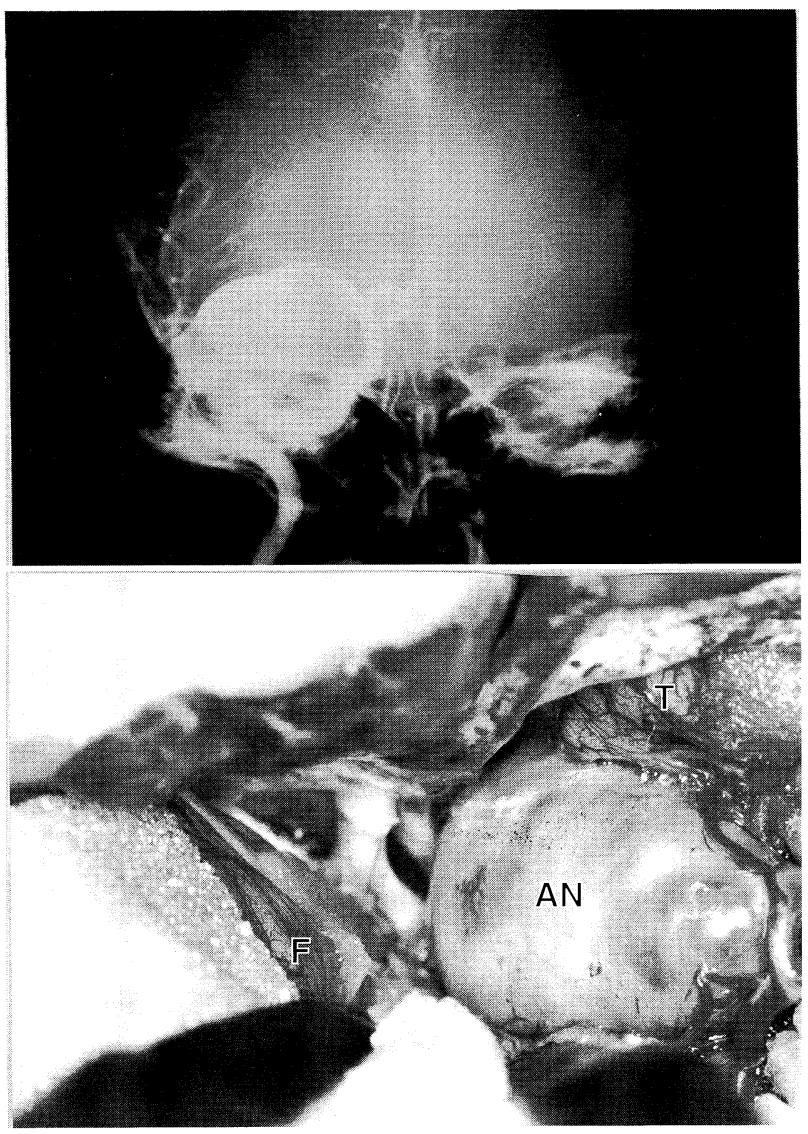

Fig. 3 An angiogram showing a giant middle cerebral artery (MCA) fusiform aneurysm (A). Intraoperatively, the internal cerebral artery (ICA), the proximal portion of the

A MCA, and the surface of the aneurysmal dome could

B be observed with less brain retraction via subfrontal route with OCA (B). AN, aneurysm; F, right frontal lobe; T, right temporal lobe.

露出できた(Fig. 2)，前頭蓋底より高さ $12 \mathrm{~mm}$ 以下で下お よび前向きの AC瘤には OCA は不要で, 従来のPAで十 分であった。

2) $\mathrm{MCA}$ 瘤例 (6例)：脳内血腫を伴った急性期の脳腫脹 例では前頭葉を強く圧排しても subfrontal routeでは十分 な術野が得られないことが多いが， orbitotomyを加える ことで瘤までの距離が短縮し，わずかな前頭葉の圧排で瘤 の近位部の親血管 (M1 segment)を確保して安全な clippingができた。また大型〜巨大瘤例では脳が十分に退縮 しても，PAでは瘤周囲の観察のために前頭葉の強い圧排 を強いられる場合が多いが，OCAにより瘤までの距離が 短縮し，少ない前頭葉の圧排で広い術野が得られ，多方向 からの観察ができた。特に early bifurcation 部やM1 segmentの fusiform typeの巨大瘤例 (Fig. 3)などでは OCA は非常に有用であった。

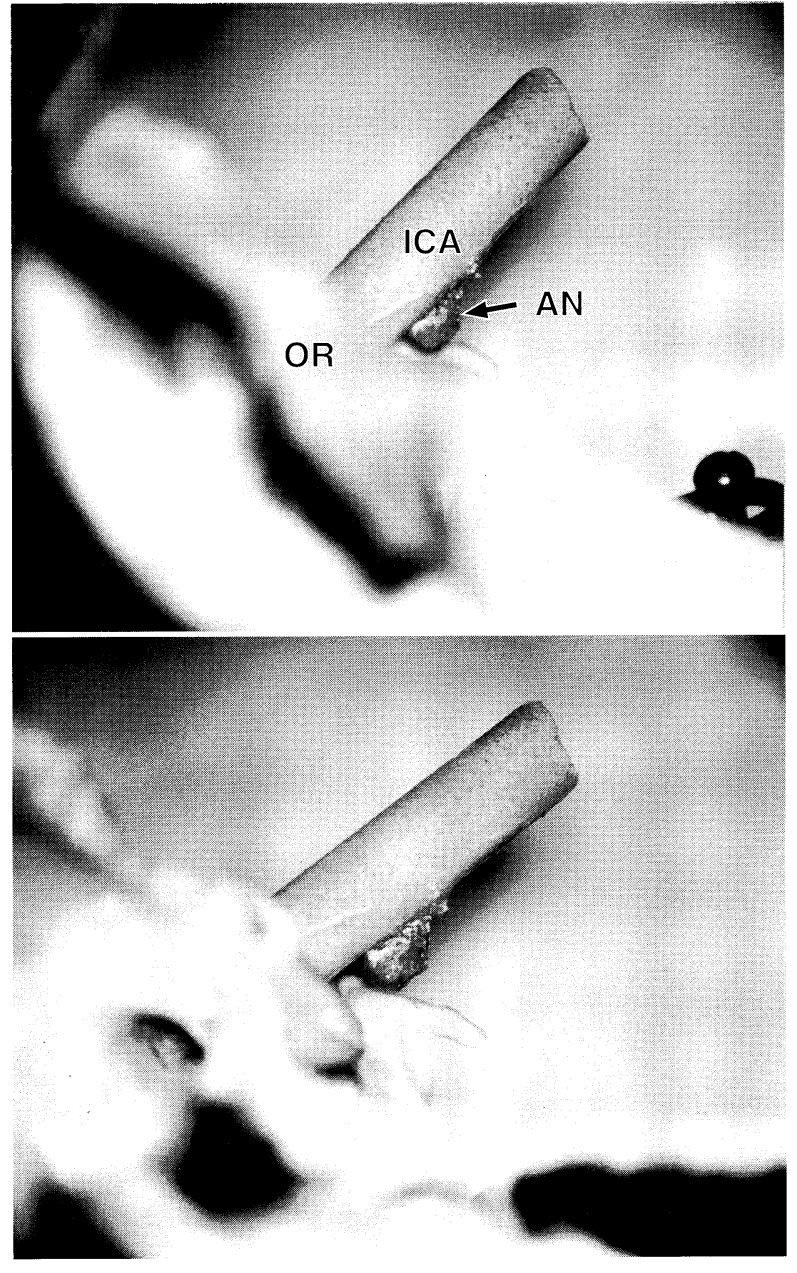

Fig. 4 Surgeon's views through the pterional approach (PA) and OCA in a skull model. When approaching the posteriorly projecting ICA aneurysm, lower visual axis and wider working space could be obtained by partial $\frac{\mathbf{A}}{\mathbf{B}}$ removal of the orbital rim $(O C A)(\mathbf{A})$ than PA (B). OR orbital rim; ICA, internal carotid artery, AN, ICPC aneurysm.

3） ICPC 瘤例 (12 例)：頭蓋内 ICAの長さが $10 \mathrm{~mm}$ 以下 と短く前床突起の骨削除を要する例では, 瘤までの距離短 縮と広い術野によりドリル操作は安全となった. 後方向き の瘤にも眼窩外側縁の orbitotomyにより PAよりもさら に外下方からの temporopolar routeにより完全クリッピ ングができ, 後交通動脈穿通枝の温存も確認できた (Fig. 4). broad neckの大型瘤に対しても同様に多方向か らの術野が確保でき，有空クリップを用いた安全なクリッ ピングができた。 $10 \mathrm{~mm}$ 以上の頭蓋内 ICA 例では本法は あまり有用ではないが，急性期の胹腫脹例では有用であっ た。

4） ICOP瘤例 (6 例)：眼動脈分枝部の ICOP瘤 (1例), 

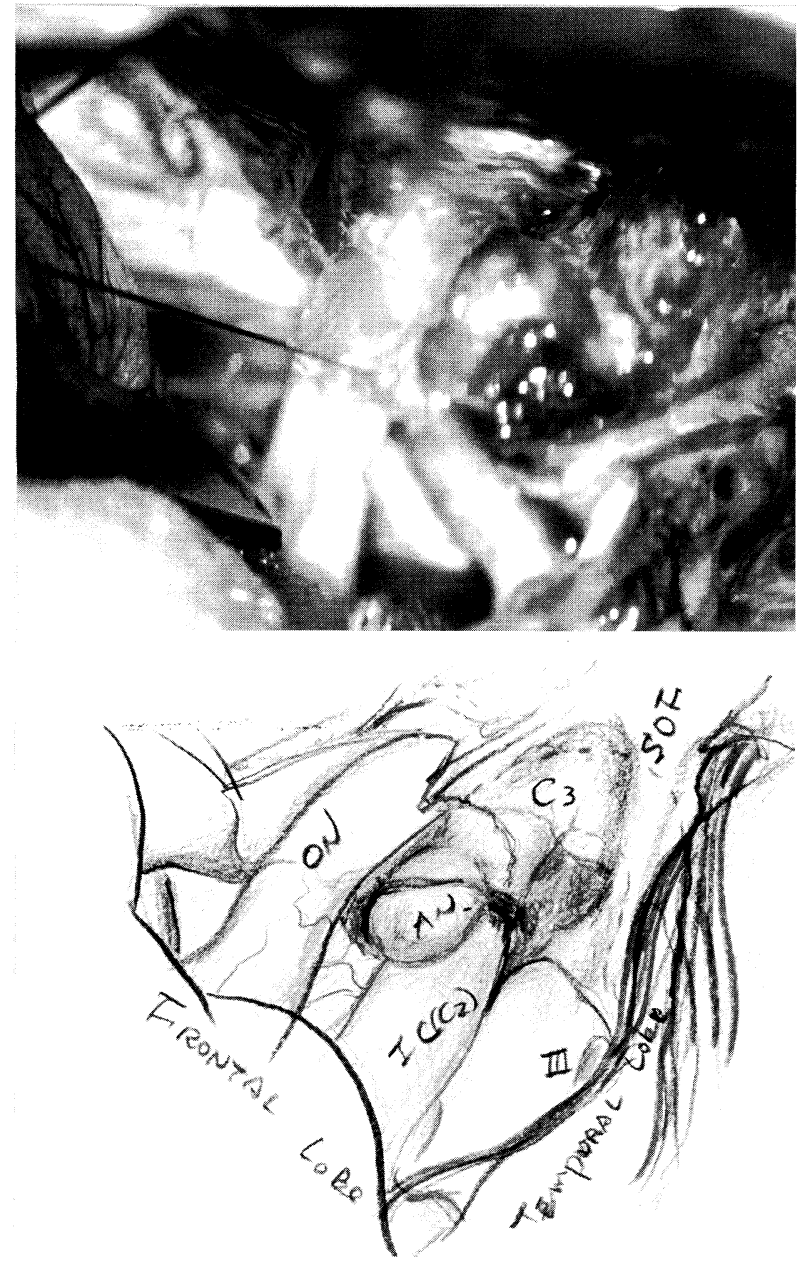

Fig. 5 The exposure of the juxta-dural ring IC dorsal aneurysm after decompression of the optic nerve and anterior cli-

$\mathbf{A}$ noid resection with OCA. An intraoperative photo $(\mathbf{A})$ and its schematic drawing (B).
IC-superior hypophyseal artery瘤 (suprasellar variant) ${ }^{2)}$ (2 例), juxta-dural ring portion の IC dorsal 瘤 ${ }^{9)}$ (1 例), IC cave 瘤 ${ }^{8}$ (ICC, 2 例) に対し, 眼窩骨縁削除に続いて orbital roof 外側除去, 上眼窩裂開放, Dolenc's approach ${ }^{3)}$ (前床突起除去, 海綿静脈洞 anteromedial triangle 部開 放), 視束管 unroofing が前頭葉の少ない圧排で安全に行 えた(Fig. 5).これにより視神経やICAの可動性が増し, 海綿静脈洞内での ICAの clinoidal segmentの確保ができ, 瘤までの手術距離は短縮し，少ない脳圧排にもかかわらず 広い術野内で容易に完全クリッピングができた。

5）ICC (3 例)：OCAにより Dolenc's approachだけで なく,さらに中頭蓋窩を硬膜外に剥離して, 海綿静脈洞 を容易に開放しICAのC4 segmentを露出できた. ICCは 全例, 大型のC4 segmentの未破裂瘤で, 瘤頸部クリッピ ングを試みたがうまくゆかず，結局 trapping とした。こ の OCA では硬膜を介した側頭葉の軽度の圧排を要する が, 広い術野が得られ多方向からの観察と手術操作が可能 であった。

6) $\operatorname{BASCA}(2$ 例) およびBA tip 瘤 (1例)：頭蓋内 ICA の長さが $1 \mathrm{~cm}$ 以上でも BA瘤が前〜後床突起間線より 10 $\mathrm{mm}$ 以上高位のものに対しては, PCA ではクリッピング の困難な例が多く，特に急性期の脳腫脹例では OCA が有 用であった。 OCA でPAよりもさらに低い位置より見上 げる視軸が得られ (Fig. 1), carotid-oculomotor triangular spaceより少ない脳圧排で容易にクリッピングができた (Fig. 6).
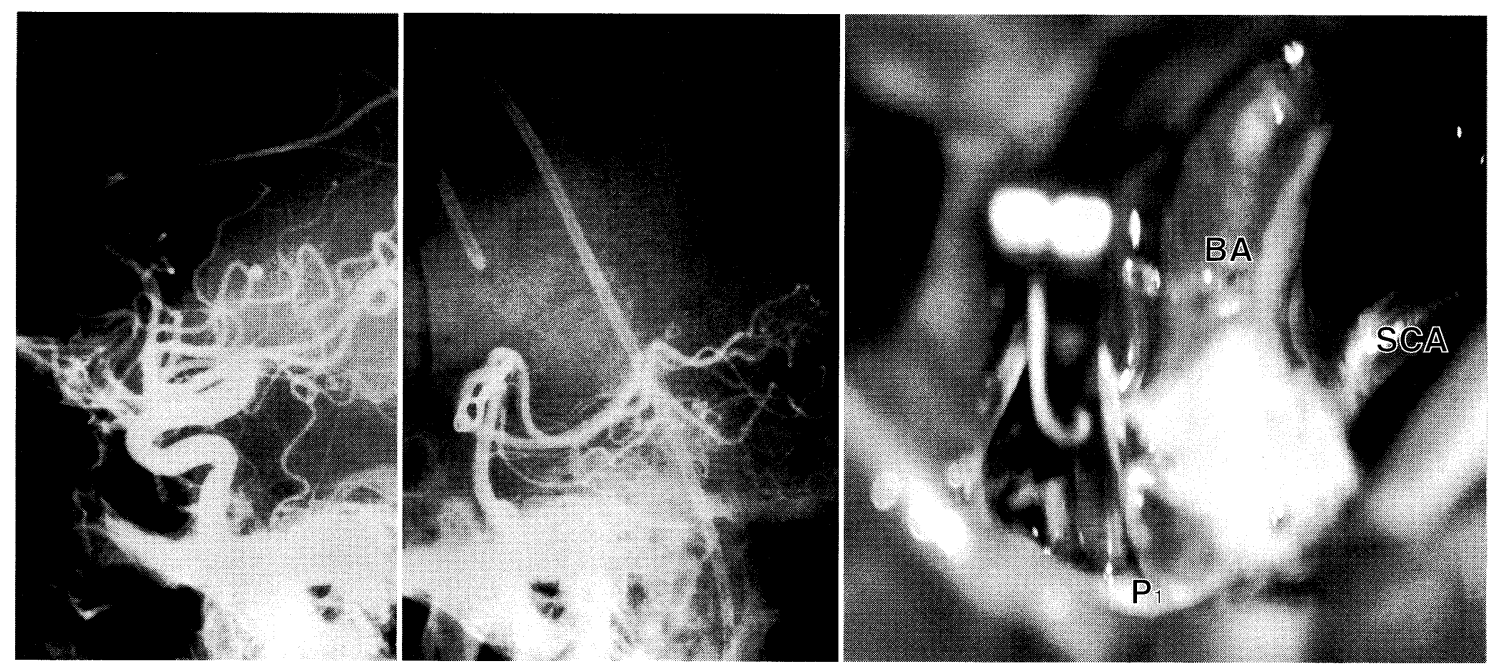

Fig. 6 Carotid and vertebral angiograms after clipping a ruptured high basilar-superior cerebellar artery aneurysm associated with a long intracranial ICA (A and $\mathbf{B})$. An intraoperative photo A $\mid$ B $\mid$ C showing complete clipping of the aneurysm in the wide working space with OCA (C). 


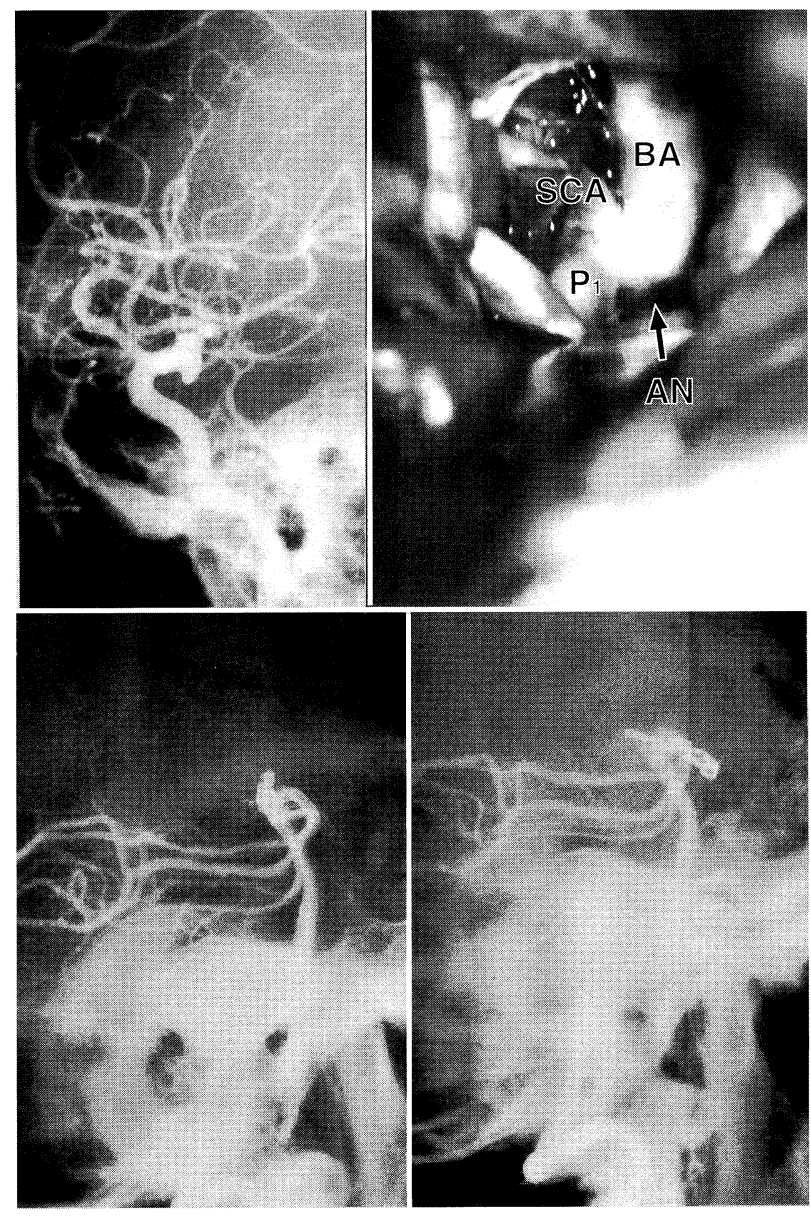

Fig. 7 Carotid and vertebral angiograms before and after clipping a high basilar tip aneurysm associated with a short

$\mathbf{A} \mid \mathbf{C}$ intracranial ICA $(\mathbf{A}$ and $\mathbf{B})$. An intraoperative photo show-

B ing complete clipping of the aneurysm with the orbitozygomatic temporopolar approach $(\mathbf{C})$

\section{OZTA(BA tip 瘤 3 例)}

頭蓋内 ICA が $10 \mathrm{~mm}$ 以下と短く前〜後床突起間線より $10 \mathrm{~mm}$ 以上高位の BA tip 瘤例に対して en blockの frontotemporal craniotomy + orbitozygomatic osteotomy 行い，さらに temporal baseの一部を骨削除することによ り，OCAよりもさらに低い位置より見上げる視軸が得ら れた (Fig. 1). そして側頭葉先端部を上外側に圧排して OCA りりさらに外側から見上げることにより, 短い頭 蓋内 ICA 例でも temporopolar routeで広い術野 (carotidoculomotor-tentorial triangular space) で容易に clipping できた(Fig. 7).

\section{3. 頭蓋底手術の合併症}

Dolenc's approach や海綿静脈洞開放例の骨欠損部に対
して, 脂肪組織の充填とフィブリン糊の補填を行った. 前頭洞開放例には洞内の十分な粘膜除去のうえ，洞開口部 を塞がないように骨内板で座板を敷き骨屑とフィブリン糊 で充填し，最後に galeaで覆った。骨削除した orbital roof の補媜整復は行わなかったが, 術後, 眼球陥四は生じな かった，術後，皮下液貯留を 10 例に，髄膜炎を 2 例に認 めたが, 一過性であった。

\section{考察}

ウイリス輪前半部ならびに $\mathrm{BA}$ tip 瘤に対しては $\mathrm{PA}^{13)}$ が現在では一般的である。しかし，高位の BA tip 瘤や $\mathrm{AC}$ 瘤に対し PAでは術野の確保に限界があり, クリッピ ングに際して非常に強い脳圧排を強いられる.脳腫脤の強 いSAH急性期例ではその限界はさらに狭められる。OCA はPAの前頭骨 key holeに近接する眼䆚上縁の一部をさら に骨削除して,ょり下方からの視軸により少ない脳圧排で, 高位の瘤へより近距離でアプローチできる有用な手術法で ある ${ }^{11)}$ 。われわれは脳脊䯚液のドレナージをしてもなお 脳腫脹の強いくも膜下出血急性期例に, 脳圧排操作を減じ る目的で OCAの手術適応はあると考えている.

$\mathrm{AC}$ 瘤については前頭葉への圧排を極力回避し gyrus rectusの吸引除去を減じる目的で通常の AC瘤に対しても 頭蓋底手術（orbital rim の除去）を選択する報告も少なくな ( ${ }^{4)}$ 11). しかし一般的にはやや高位のものが適応とされ 11)，われわれの経験では前頭蓋底より $12 \mathrm{~mm}$ 以上のもの に有用であった。一般に高位で後方向きの AC瘤や proximal A2瘤には interhemispheric approachが適応となる が, 術野や working space は狭く脳腫脹例では広範な半球 間裂の切離は熟達した脳外科医でも困難となることが多 い. OCA で orbitotomyをより正中近くに行うことにより， 少ない前頭葉の圧排での subfrontal routeが容易となっ た.

ICA 近位部の瘤 (ICOP, ICC) や頭蓋内 ICA の短い ICPC 瘤については瘤の近位側の親動脈碓保のため，障壁となる 前床突起や視神経管上壁を十分に削除することは非常に有 用である ${ }^{8)}$.これにより ICA と視神経の可動性が増し, 安全な親血管と視神経の移動, 多方向からの視軸と広い術 野が確保できる。一般にPAにより Dolenc’s approach は 行われているが, orbitotomyを加えることにより少ない 前頭葉の圧排で drilling 操作は非常に安全となる.

MCA 瘤は一般にはPAで十分な術野が得られるが, $\mathrm{SAH}$ の急性期の脳腫脹例, 瘤近位側の親動脈確保が困難 と思われる大型〜巨大瘤例などに対してOCA はその有用 性を発揮し, 多方向からの視軸と広範な術野を提供する。

BA tip 瘤のアプローチの困難さは深部に存在する瘤に 対して狭い術野内での操作に起因する. 特に瘤が前 - 後床 
突起間線より $10 \mathrm{~mm}$ 以上高位で, 頭蓋内 ICAの長さが $10 \mathrm{~mm}$ 以下と短い症例に対してはPAでは手術成績は不良 とされている ${ }^{12)}$.このような症例に対し，われわれの開 発した OZTA ${ }^{6)}$ はPAやOCA より, さらに下外側からの 視軸が得られ carotid-oculomotor-tentorial triangular spaceからの安全なクリッピングを可能とした。初期の OZTA では temporopolar routeの確保のため䁚頭葉先端 の bridging veinを切断した。これまで側頭葉内の静脈性 梗塞を生じたことはないが，最近では extradural temporopolar approachにより bridging veinを温存している. 一方，高位のBA tip BASCA 瘤でICA が十分な長さの 急性期例にはOCA も適応となる。OCA は広い術野内で 多方向からの視軸が得られ, 瘤までの操作距離がより近づ くことにより, PAでの過度な脳圧排による狭い術野内で の手術よりも安全性が増すため, 経験の少ない術者には推 奨される方法である。

最近, less invasive neurosurgeryが唱われ, 頭蓋底手 術の侵襲度が問題視されている。しかし, 脳動脈瘤に対し て少ない脳圧排で多方向からの視軸と広い術野が得られ， 瘤までの手術操作距離が短縮し安全で容易なクリッピング が可能となる頭蓋底手術アプローチは捨て切れない。脳動 脈瘤の術野と working spaceの広さは単にクリッピングす るだけの視軸を確保するだけのものではなく, 周囲の神経 構造物の損傷を避け, 瘤背後の穿通枝の温存にまで注意を 払った安全な手術操作を可能とするものでなくてはならな い.もちろん, 不必要な開頭, 骨削除は避けるべきであり, 経験に伴い無䭾な手術操作は減らしていかねばならない。 最後にわれわれ, 脳神経外科医の目指す真の less invasive neurosurgery とは『いかに脳神経を愛護的に手術操作す るか』ではないだろうか.

\section{結 論}

高位ならびに媣部脳動脈瘤に対して頭蓋底手術アプロー 千の選択により，少ない脳圧排で多方向からの視軸と広い 術野が得られ，瘤までの手術操作距離が短縮することによ
り安全で容易なクリッピングが可能となった.

\section{文献}

1) Al-Mefty O, Fox JL, Smith RR: Petrosal approach for petroclival meningiomas. Neurosurgery 22: 510-517, 1988

2) Day AL: Aneurysms of the ophthalmic segment: A clinical and anatomical analysis. J Neurosurg 72: 677-691, 1996

3) Dolenc VV: A combined epi- and subdural direct approach to carotid-ophthalmic artery aneurysms. J Neurosurg 62: 667-672, 1985

4) Fujitu K, Kuwabara T: Orbitocraniobasal approach for anterior communicating artery aneurysms. Neurosurgery 18: 367-369, 1986

5) Heros RC: Lateral suboccipital approach for vertebrobasilar artery lesions. J Neurosurg 64: 559-562, 1986

6) Ikeda K, Yamashita J, Hashimoto M, et al: Orbitozygomatic temporopolar approach for a high basilar tip aneurysm associated with a short intracranial internal carotid artery: A new surgical approach. Neurosurgery 28 (1): 105-110, 1991

7) 河瀬 斌, Helmut Bertalanffy, 塩原隆造, ほか：傍正中 VA aneurysmに対する (Trans-) Condylar ApproachSuboccipital approachとの比較一. 脳卒中の外科 21 : 263-268, 1993

8) Kobayashi S, Kyoshima K, Gibo H, et al: Carotid cave aneuryms of the internal carotid artery. J Neurosurg 70: 216-221, 1989

9) Nakagawa F, Kobayashi S, Takemae T, et al: Aneurysms protruding from the dorsal wall of the internal carotid artery. J Neurosurg 65: 303-308, 1986

10) Sekhar LN, Kalia KK, Yonas H, et al: Cranial base approaches to intracranial aneurysms in the subarachnoid space. Neurosurgery 35: 472-481, 1994

11) Smith RR, Al-Mefty O, Middleton TH: An orbitocranial approach to complex aneurysms of the anterior circulation. Neurosurgery 24: 385-391, 1989

12) Yamaura A, Ise $H$, Makino $H$ : Treatment of aneurysms arising from the terminal portion of the basilar artery: With special reference to the radiometric study and accessibility of trans-sylvian approach. Neurol Med Chir (Tokyo) 22: 521-532, 1982

13) Yaşargil MG, Antic J, Laciga R, et al: Microsurgical pterional approach to aneurysms of the basilar bifurcation. Surg Neurol 6: 83-91, 1976 